\title{
PENGARUH KEPUASAN KERJA, MOTIVASI BERPRESTASI DAN \\ KEDISIPLINAN TERHADAP KINERJA GURU ( STUDI PADA GURU \\ SEKOLAH MENENGAH ATAS DAN SEKOLAH MENENGAH \\ KEJURUAN SE KECAMATAN PEBAYURAN KABUPATEN BEKASI )
}

Oleh:

Ade Nurali

nuraliade@yahoo.co.id

\begin{abstract}
ABSTRAK
Masalah yang diangkat dalam penelitian ini adalah : untuk mengetahui, menjelaskan dan menganalisis Kepuasan Kerja, Motivasi Berprestasi dan Kedisiplinan Terhadap Kinerja Guru serta pengaruh parsial dan simultan Kepuasan Kerja, Motivasi Berprestasi dan Kedisiplinan Terhadap Kinerja Guru Pada Guru Sekolah Menengah Atas dan Sekolah Menengah Kejuruan Se Kecamatan Pebayuran Kabupaten Bekasi.

Jumlah sampel yang diambil sebanyak 151 orang guru dengan teknik sampling jenuh. Tesis ini diharapkan dapat memberikan sumbangan bagi pengembangan bidang manajemen khususnya manajemen sumber daya manusia. Metode penelitian yang digunakan penulis dalam penelitian ini menggunakan metode deskriptif dan verifikatif, dari hasil analisis data penelitian diperoleh beberapa kesimpulan sebagai berikut : (1) Kinerja Guru pada Sekolah Menengah Atas dan Sekolah Menengah Kejuruan Se Kecamatan Pebayuran Kabupaten Bekasi cukup baik. (2) Kepusan Kerja pada Sekolah Menengah Atas dan Sekolah Menengah Kejuruan Se Kecamatan Pebayuran Kabupaten Bekasi cukup baik. (3) Motivasi Berprestasi pada Sekolah Menengah Atas dan Sekolah Menengah Kejuruan Se Kecamatan Pebayuran Kabupaten Bekasi cukup baik. (4) Kedisiplinan pada Sekolah Menengah Atas dan Sekolah Menengah Kejuruan Se Kecamatan Pebayuran Kabupaten Bekasi cukup baik. (5) Terdapat pengaruh parsial antara Kepuasan Kerja terhadap Kinerja Guru sebesar 76,3 \% dan terdapat pengaruh parsial antara Motivasi Berprestasi terhadap Kinerja Guru sebesar 69,3 $\%$ kemudian berpengaruh parsial Kedisiplinan terhadap Kinerja Guru sebesar 65,6 \% (6 ) Kepuasan Kerja, Motivasi Berprestasi dan Kedisiplinan secara simultan berpengaruh positif dan signifikan terhadap Kinerja Guru. Total pengaruh yang disebabkan Kepuasan Kerja (X1), Motivasi Berprestasi (X2) dan Kedisiplinan (X3) terhadap Kinerja Guru (Y) yaitu sebesar 82,6\%.
\end{abstract}

Kata Kunci : Kepuasan Kerja, Motivasi Berprestasi, Kedisiplinan dan Kinerja

74. 


\title{
THE INFLUENCE OF JOB SATISFACTION, ACHIEVMENT MOTIVATION AND DICIPLINE OF WORK AGAINTS TEACHER PERFORMANCE ( STUDY ON SENIOR AND VOCATIONAL HIGH SCHOOL IN PEBAYURAN BEKASI REGENCY ).
}

\author{
Ade Nurali \\ nuraliade@yahoo.co.id
}

\begin{abstract}
ABSTRACK
The issues raised in this study are: to know, to explain and to analyze Job Satisfaction, Achievment Motivation and Dicipline of Work Againts teachers Performance as well as partial and simultaneous influence of Job Satisfaction, Achievment Motivation and Dicipline of Work Againts teachers Performance Study On Senior And Vocational High School In Pebayuran Bekasi Regency.
\end{abstract}

151 teachers are taken as a sample using saturation sampling technique. This thesis is expected to contribute to the development in manajement field, especially human resources management. The research methods used by the author in this wrating are descriptive and verification methods. From the result of the research data analysis, some conclusions are obtained as follow: ( 1 ) teachers Performance On Senior And Vocational High School In Pebayuran Bekasi Regency is good. ( 2 ) Job Satisfaction On Senior And Vocational High School In Pebayuran Bekasi Regency is good. ( 3 ) Achievment Motivation On Senior And Vocational High School In Pebayuran Bekasi Regency is good. ( 4 ) Dicipline of Work Againts On Senior And Vocational High School In Pebayuran Bekasi Regency is good. ( 5 ) There is 76,3\% partial influence of Job Satisfaction on teachers Performance and there is 69,3 partial infleunce of Achievment Motivation on Teachers Performance and 65,6\% partial influence of Dicipline on Teachers Performance. ( 6 ) Job Satisfaction, Achievment Motivation and Dicipline of Work Againts simultaneously have a positive and significant effect on Teachers Performance. Total influence caused by Job Satisfaction (X1), Achievment Motivation (X2), Dicipline of Work Againts (X3) on Teachers Performace ( $\mathrm{Y}$ ) is equal to $82,6 \%$.

Keywords : Job Satisfaction, Achievment Motivation, Dicipline and Teachers Performace

75. Jurnal Manajemen \&

Bisnis Kreatif 


\section{PENDAHULUAN}

Kemajuan suatu bangsa tidak dapat lepas dari sumber daya manusia yang dimiliki oleh bangsa tersebut. Sumber daya manusia merupakan salah satu asset paling berharga yang dimiliki oleh suatu organisasi, karena manusialah yang merupakan satu-satunya sumber daya yang dapat menggerakkan sumber daya lainnya. Dengan demikian, unsur sumber daya manusia merupakan faktor kunci yang harus dipertahankan suatu organisasi sejalan dengan tuntutan yang senantiasa dihadapi organisasi untuk menjawab setiap tantangan yang ada. Oleh karena itu, upaya untuk mempertahankan sumber daya manusia yang berkualitas merupakan langkah utama organisasi.

Baik buruknya kualitas sumber daya manusia yang ada menjadi tolok ukur majunya perkembangan suatu bangsa. Adapun sarana yang dapat mempengaruhi baik tidaknya kualitas sumber daya manusia dipengaruhi oleh baik tidaknya sistem pendidikan yang ada, hal ini tentunya memerlukan upaya secara terus menerus dari pemerintah baik daerah maupun pusat untuk menjamin terselenggaranya pendidikan yang bermutu bagi setiap warga negaranya. Pendidikan merupakan wahana yang sangat strategis dalam meningkatkan kualitas sumber daya manusia yang merupakan faktor determinan pembangunan.

Guru merupakan sumber daya manusia yang mampu mendayagunakan faktor-faktor lainnya sehingga tercipta Proses Belajar mengajar yang bermutu dan menjadi faktor utama yang menentukan mutu pendidikan di Indonesia. Guru juga merupakan salah satu unsur di bidang kependidikan yang harus berperan secara aktif dan menempatkan kedudukannya sebagai tenaga profesional sesuai dengan tuntutan masyarakat pada saat ini. Kinerja dari guru tersebut akan mempengaruhi keberhasilan siswa dalam belajar yang berujung pada peningkatan mutu pendidikan. Untuk itu guru dituntut untuk dapat meningkatkan kinerja dalam menjalankan tugasnya.

Kecamatan Pebayuran merupakan salah satu kecamatan yang terletak di kabupaten Bekasi banyak terdapat Sekolah Menengah Atas dan Sekolah Menengah Kejuruan. Keberadaan kedua sekolah tersebut sangat dibutuhkan dalam rangka pencapaian visi dan misi Dinas pendidikan Propinsi Jawa Barat tahun 2013-2018 yaitu terwujudnya pendidikan maju di Jawa barat guna membentuk SDM yang berkarakter, cerdas, mandiri menguasai IPTEK dan berbasis budaya Jawa Barat. Untuk mewujudkan hal tersebut guru pada kedua sekolah tersebut dituntut untuk meningkatkan kinerjanya agar tercipta lulusan yang baik serta mampu bersaing dalam dunia kerja. Salah satu indikator kinerja guru dapat dilihat dari hasil ujian nasional peserta didiknya. Berikut adalah data rata-rata hasil ujian nasional SMA dan SMK se kecamatan pebayuran tahun 2014 sampai dengan 2016.

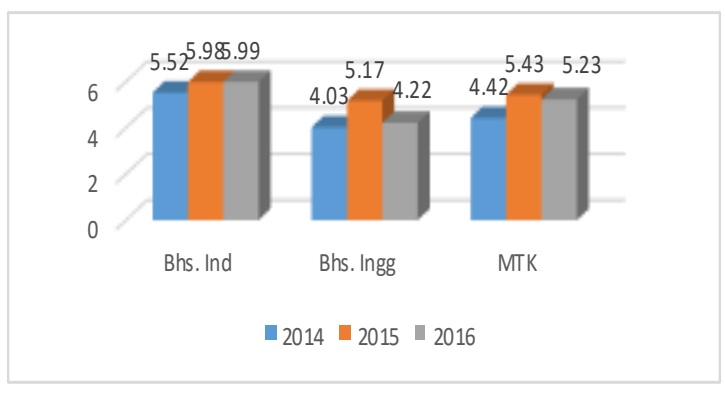

Sumber: Hasil Ujian SMA se Kecamatan Pebayuran 


\section{Gambar 1.1 \\ Hasil Ujian Nasional SMA se Kecamatan Pebayuran}

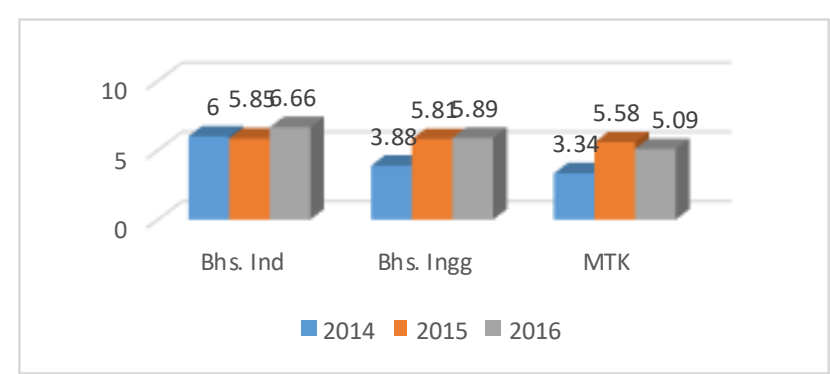

Sumber: Hasil Ujian SMK se Kecamatan Pebayuran

\section{Gambar 1.2 \\ Hasil Ujian Nasional SMK se Kecamatan Pebayuran}

Berdasarkan data diatas dapat ditarik kesimpulan bahwa hasil ujian nasional siswa SMA pada tahun 2014 s/d 2016 tersebut mengalami fluktuatif pada mata pelajaran matematika dan Bahasa inggris. Sedangkan untuk mata pelajaran Bahasa Indonesia terus meningkat. Adapun untuk SMK hanya mengalami fluktuatif pada mata pelajaran matematika saja, sementara untuk mata pelajaran yang lain cenderung meningkat. Apabila dibandingkan rata-rata nilai SMK lebih besar dibanding rata-rata nilai siswa SMA, tetapi tetap saja nilainya tidak ada yang mencapai 7.00. Hal ini menunjukan bahwa kinerja guru pada kedua sekolah tersebut diduga masih rendah. Rendahnya kinerja guru diindikasikan oleh rendahnya kepuasan kerja guru.

Kepuasan kerja pada tingkat tertentu dapat mencegah pegawai untuk mencari pekerjaan lain. Apabila pegawai tersebut mendapatkan kepuasan, pegawai cenderung akan bertahan walaupun tidak semua aspek-aspek yang mempengaruhi kepuasan kerja terpenuhi. Kepuasan kerja merupakan suatu tanggapan emosional seseorang terhadap situasi dan kondisi kerja. Marsana dan SB. Handayani (2013) dalam penelitiannya menyatakan bahwa kepuasan kerja berpengaruh positif dan signifikan terhadap kinerja guru. Didukung oleh penelitian Khairunnisa (2015) menyatakan bahwa kepuasan kerja mempunyai pengaruh yang tinggi terhadap kinerja guru. Tetapi berbeda dengan penelitian Sri Sudarmi (2016) menyatakan bahwa kepuasan kerja tidak berpengaruh terhadap kinerja guru. Tanggapan ini bisa berupa perasaan puas (positif) atau tidak puas (negatif). Bila secara emosional puas berarti kepuasan kerja tercapai dan sebaliknya bila tidak berarti pegawai tidak puas. Kepuasan kerja dirasakan pegawai setelah pegawai tersebut membandingkan antara apa yang dia harapkan akan dia peroleh dari hasil kerjanya dengan apa yang sebenarya dia peroleh dari hasil kerjanya. Berikut adalah data hasil penelitian pendahuluan kepuasan kerja yang dilakukan dengan penyebaran kuesioner pada 30 orang responden . 


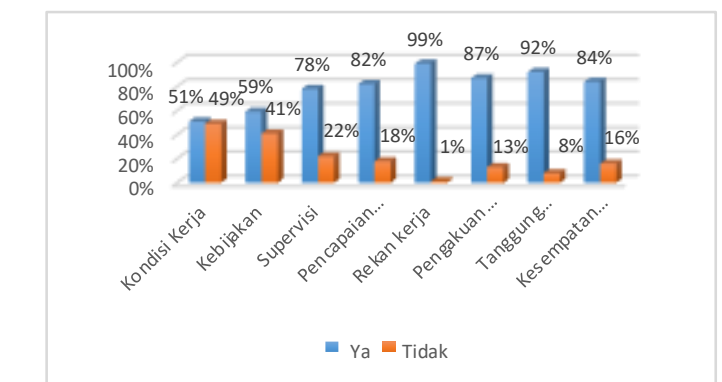

Sumber: Hasil Penelitian Pendahuluan 2017

Gambar 1.3

\section{Hasil Penelitian Pendahuluan Kepuasan Kerja}

Dari data diatas dapat dilihat bahwa rata-rata responden menjawab YA pada semua pertanyaan yang diajukan. Tapi jika dilihat dari perindikator ada beberapa responden yang menjawab TIDAK dengan presentasi yang cukup tinggi pada indikator kondisi kerja dan kebijakan. Hal ini menunjukan bahwa masih adanya beberapa guru yang belum puas dengan kondisi kerja dan kebijakan yang dikeluarkan oleh sekolah.

Faktor lain yang mempengaruhi kinerja diindikasikan oleh rendahnya motivasi berprestasi guru tersebut. Motivasi bagi anggota organisasi merupakan bagian yang begitu penting, karena merupakan salah satu faktor untuk mendukung tujuan organisasi. Motivasi juga ikut menentukan intensitas, arah, dan ketekunan individu dalam usaha mencapai sasaran. Terjadinya perbedaan motivasi dari karyawan yang bekerja dalam suatu organisasi, akan membuat setiap orang atau karyawan tersebut berperilaku dan bereaksi secara berbedabeda pada suatu jenis pekerjaan. Eka Harjanto (2015) dalam penelitiannya menyatakan bahwa variabel motivasi berprestasi memiliki pengaruh terhadap kinerja mengajar guru. Didukung oleh penelitian Sri Sudarmi (2016) menyatakan motivasi kerja berpengaruh terhadap kinerja guru. Kemudian didukung oleh penelitian Mishan (2014) dalam penelitiannya menyatakan bahwa motivasi kerja guru memberikan pengaruh yang positif dan signifikan terhadap kinerja guru. Hal ini menunjukan masih adanya permasalahan yang berhubungan antara motivasi dan kinerja. Berikut adalah data hasil penelitian pendahuluan dengan penyebaran kuesioner kepada 30 orang responden dengan pertanyaan mengenai motivasi berprestasi.

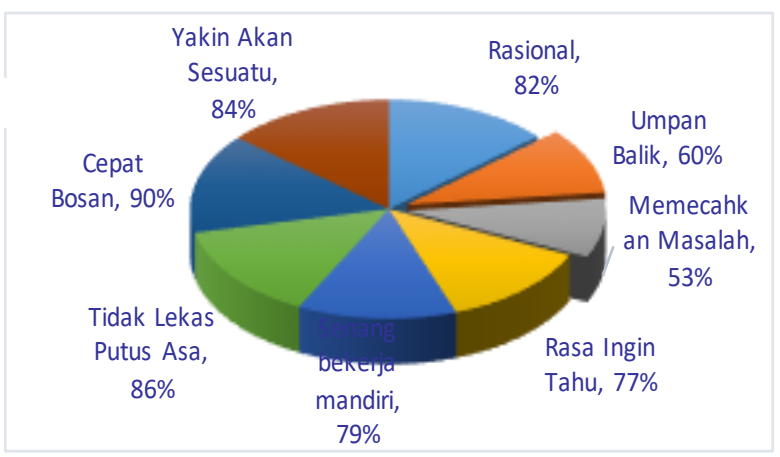

Sumber: Hasil Penelitian Pendahuluan 2017

Gambar 1.4

Hasil Penelitian Pendahuluan Motivasi Berprestasi 
Berdasarkan data diatas dapat ditarik kesimpulan bahwa rata-rata responden menjawab YA pada semua pernyataan yang diajukan. Tetapi pada indikator tertentu ada responden yang menjawab TIDAK yaitu Umpan balik dan tanggung jawab dengan presentasi lebih tinggi dibandingkan indikator lain. Hal ini menunjukkan bahwa beberapa guru merasa kurang mendapatkan umpan balik atas apa yang telah dicapainya serta kurang dibaerikan bantuan dalam memecahkan masalah pembelajaran.

Faktor berikutnya yang diduga dapat mempengaruhi kinerja guru adalah rendahnya disiplin guru tersebut. Rahmat Hasbullah dan Anoesyirwan Moeins (2017) dalam penelitiannya menyatakan bahwa "discipline of work had influenced as partially, with positive and significant on teacher performance with the contribution $85 \%$, and the remaining $15 \%$ were influenced by other factors, with Discipline work is the most dominant influence on the performance of teachers" ( Disiplin kerja memiliki pengaruh secara parsial, positif dan signifikan terhadap kinerja guru dengan kontribusi $85 \%$ dan $15 \%$ sisanya dipengaruhi oleh faktor lain, dengan disiplin kerja adalah pengaruh yang paling dominan terhadap kinerja guru). Yang didukung oleh Aninditya Sri Nugraheni \& Ratna Rahmayanti (2016) dalam penelitiannya menyatakan bahwa disipin kerja sangat berpengaruh positif dan signifikan terhadap kinerja guru. Berikut adalah hasil penelitian pendahuluan tentang disiplin kerja dengan penyebaran kuesioner kepada 30 orang responden.

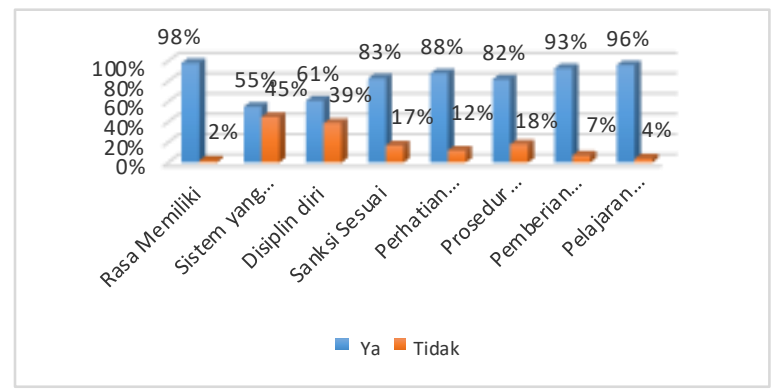

Sumber : Hasil penelitian pendahuluan 2017

Grafik. 1.5

\section{Hasil Survei Pendahuluan Disiplin kerja}

Berdasarkan data diatas rata-rata responden menjawab YA atas pertanyaan yang diajukan mengenai disiplin kerja. Tetapi apabila dilihat per indikator terdapat responden yang menjawab TIDAK dengan presentasi yang cukup besar yaitu pada indikator sistem yang baik dan disiplin diri. Hal ini menunjukan bahwa masih adanya beberapa yang belum bisa menerapkan sistem yang baik dan memiliki disiplin diri yang tinggi dalam melaksanakan tugasnya sebagai pendidik.

Berdasarkan fenomena tersebut, peneliti tertarik untuk melakukan penelitian yang mempengaruhi Kinerja Guru. Dimana aspek Kepuasan Kerja, Motivasi Berprestasi dan Disiplin Kerja yang akan diteliti. Sehingga peneliti mengambil judul tesis "Pengaruh Kepuasan Kerja, Motivasi Berprestasi dan Disiplin Kerja Terhadap Kinerja Guru (Studi Pada Sekolah Menegah Atas dan Sekolah Menengah Kejuruan Se Kecamatan Pebayuran Kabupaten Bekasi”. 


\section{IDENTIFIKASI MASALAH}

Mengacu pada latar belakang penelitian diatas, maka identifikasi masalah dalam penelitian ini adalah :

1. Rendahnya kinerja guru SMA dan SMK di kecamatan Pebayuran, bisa dilihat dari rendahnya nilai UN

2. Rendahnya Nilai Ujian nasional diduga karena kinerja guru yang rendah

3. Rendahnya kinerja guru juga dapat diindikasikan oleh rendahnya kepuasan kerja

4. Rendahnya kinerja guru juga disinyalir dari rendahnya motivasi berprestasi guru

5. Selain itu rendahnya kinerja guru diduga karena rendahnya disiplin guru

6. Masih rendahnya motivasi berprestasi guru hal ini terlihat pada rendahnya indikator umpan balik atas apa yang telah dicapainya

7. Masih rendahnya motivasi berprestasi guru hal ini terlihat pada kurangnya diberikan bantuan dalam memecahkan masalah pemebelajaran

8. Masih rendahnya Disiplin kerja guru hal ini terlihat pada kurang menerapkan sistem yang baik dalam menjalankan pekerjaannya

9. Masih rendahnya Disiplin kerja guru, hal ini terlihat pada kurangnya penerapan disiplin diri dalam menjalankan tugasnya sebagai pendidik

\section{PEMBATASAN MASALAH}

Adapun pembatasan masalah tersebut adalah sebagai berikut:

1. Bidang ilmu yang diteliti adalah Manajemen khususnya Manajemen Sumber Daya Manusia.

2. Tema penelitian yang diangkat adalah Pengaruh kepuasan kerja, motivasi berprestasi dan disiplin kerja terhadap kinerja guru.

3. Penelitian ini dilakukan di SMA dan SMK Se Kecamatan Pebayuran Kabupaten Bekasi

4. Metode analisis yang akan digunakan adalah metode deskriptif dan verifikatif dengan menggunakan alat bantu SPSS.

5. Responden yang akan diambil yaitu Guru SMA dan SMK se Kecamatan Pebayuran kabupaten Bekasi

\section{RUMUSAN MASALAH}

Adapun rumusan masalah yang akan dikaji dalam penelitian ini adalah sebagai berikut :

1. Bagaimana kinerja guru di SMA dan SMK se Kecamatan Pebayuran Kabupaten Bekasi ?

2. Bagaimana kepuasan kerja guru di SMA dan SMK se Kecamatan Pebayuran Kabupaten Bekasi ?

3. Bagaimana motivasi berprestasi guru di SMA dan SMK se Kecamatan Pebayuran Kabupaten Bekasi?

4. Bagaimana disiplin kerja guru di SMA dan SMK se Kecamatan Pebayuran Kabupaten Bekasi ?

5. Seberapa Besar pengaruh parsial Kepuasan Kerja, motivasi berprestasi dan disiplin kerja terhadap Kinerja Guru di SMA dan SMK se Kecamatan Pebayuran Kabupaten Bekasi?

6. Seberapa besar pengaruh simultan Kepuasan Kerja, motivasi berprestasi dan disiplin kerja terhadap Kinerja Guru SMA dan SMK se Kecamatan Pebayuran Kabupaten Bekasi? 


\section{TUJUAN PENELITIAN}

Penelitian ini bertujan untuk mengetahui dan mengkaji :

1. Kinerja guru di SMA dan SMK se Kecamatan Pebayuran Kabupaten Bekasi

2. Kepuasan kerja SMA dan SMK se Kecamatan Pebayuran Kabupaten Bekasi

3. Motivasi berprestasi guru di SMA dan SMK se Kecamatan Pebayuran Kabupaten Bekasi

4. Disiplin kerja guru di SMA dan SMK se Kecamatan Pebayuran Kabupaten Bekasi

5. Besarnya pengaruh parsial Kepuasan Kerja, motivasi berprestasi dan disiplin kerja terhadap Kinerja Guru di SMA dan SMK se Kecamatan Pebayuran Kabupaten Bekasi

6. Besarnya pengaruh simultan Kepuasan Kerja, motivasi berprestasi dan disiplin kerja terhadap Kinerja Guru di SMA dan SMK se Kecamatan Pebayuran Kabupaten Bekasi

\section{TINJAUAN PUSTAKA}

\section{KEPUASAN KERJA}

Menurut Newstrom dalam Khikmawati (2015:32) bahwa job satisfaction is the favorableness or unfavorableness with employes view their work. Kepuasan kerja berarti perasaan mendukung atau tidak mendukung yang dialami karyawan dalam bekerja. Sementara itu, menurut Happock dalam Parimita (2013:261) mengatakan "job satisfaction as any combination of psychological and environmental circumstances that cause a person thruthfully to say, I am satisfied with my job". Dalam arti bebas kepuasan kerja merupakan kombinasi dari keadaan psikologi, fisiologi, dan lingkungan yang menyebabkan seseorang jujur untuk mengatakan, saya puas dengan pekerjaan saya.

Sedangkan menurut Veithzal (2010:856) bahwa kepuasan kerja merupakan evaluasi yang menggambarkan seseorang atas perasaan sikapnya senang atau tidak senang, puas atau tidak puas dalam bekerja. Handoko (2011:193) menyatakan bahwa kepuasan kerja adalah keadaan emosional yang menyenangkan atau tidak menyenangkan dengan mana para karyawan memandang pekerjaan mereka .

Keith davis sebagaimana dikutip oleh Anwar Prabu mangkunegara (2008:117) mengemukakan bahwa "job satisfaction Is the favorableness or unfavorableness with employees view their work". Yang artinya adalah kepuasan kerja yaitu adalah perasaan menyokong atau tidak menyokong yang dialami pegawai dalam bekerja. Sedangkan Wexley dan Yukl mendefinisikan kepuasan kerja sebgai berikut "is the way an employees feels about his or her job", yang artinya adalah cara pegawai merasakan dirinya atau pekerjaannya.

\section{MOTIVASI BERPRESTASI}

Menurut Stephen P. Robbins dan Mary Counter dalam buku Suwanto dan Donni Juni Priansa (2011:171) menyatakan motivasi adalah kesediaan untuk melaksanakan upaya tinggi untuk mencapai tujuan-tujuan keorganisasian yang dikondisikan oleh kemampuan upaya untuk memenuhi kebutuhan individu tertentu.

Sedangkan definisi menurut Robbins dalam buku Edy Sutrisno (2009:111) mengemukakan motivasi adalah suatu kerelaan berusaha seoptimal mungkin dalam pencapaian tujuan organisasi yang dipengaruhi oleh kemampuan usaha memuaskan beberapa kebutuhan individu.

Menurut Handoko (2012:43) "Motivasi berprestasi adalah kecendrungan untuk mencapai sukses atau memperoleh apa yang menjadi tujuan akhir yang dikehendaki. Keinginan untuk memperoleh kesuksesan dianggap sebagai pendorong”. 
McClelland dalam Reni Akbar-Hawadi (2003:43) mengatakan bahwa motivasi berprestasi adalah motif yang mengarahkan tingkah laku seseorang dengan titik berat pada bagaimana prestasi tersebut dicapai dan bersaing dengan suatu standar keunggulan tertentu. Motivasi berprestasi mendorong individu untuk melakukan sesuatu dengan lebih baik berdasarkan suatu standar keunggulan. Standar keunggulan tersebut dapat berhubungan dengan prestasi orang lain; prestasi diri sendiri yang lampau; maupun dalam hubungan dengan tugas yang artinya individu berusaha menyelesaikan tugas sebaik mungkin karena tugas tersebut tantangan bagi dirinya.

\section{DISIPLIN KERJA}

Menurut Gary Dessler (2007:194) memberikan definisi yaitu sebagai berikut: Disiplin didasarkan pada tiga pilar: peraturan dan perundang-undangan yang jelas, sistem denda yang progresif dan proses yang serius.

Menurut H. Edy Sutrisno (2009:97) mengemukakan bahwa: Disiplin kerja merupakan alat yang digunakan para manajer untuk berkomunikasi dengan karyawan agar mereka bersedia untuk mengubah suatu perilaku serta sebagai suatu upaya untuk meningkatkan kesadaran dan kesediaan seseorang menaati semua peraturan perusahaan dan norma-norma social yang berlaku.

Menurut Keith Davis yang dikutip oleh A.A. Anwar Prabu Mangkunegara (2008:129) memberikan definisi yaitu sebagai berikut: Disiplin kerja dapat diartikan sebagai pelaksanaan manajemen untuk memperteguh pedomanpedoman organisasi.

Menurut H. Abdurrahmat Fathoni (2006:126) memberikan definisi yaitu: Kedisiplinan dapat diartikan bilamana karyawan selalu datang dan pulang tepat pada waktunya, mengerjakan semua pekerjaannya dengan baik, mematuhi semua peraturan perusahaan dan norma-norma sosial yang berlaku.

\section{KEPUASAN KERJA}

Menurut Mahsum dalam buku Masana Sembiring (2012:81) "kinerja adalah gambaran mengenai tingkat pencapaian pelaksanaan suatu kegiatan/program/kebijakan dalam mewujudkan sasaran, tujuan, misi, dan visi organisasi”.

Kemudian Indra Bastian yang dikutip oleh Irham Fahmi (2011:2), Kinerja adalah gambaran mengenai tingkat pencapaian pelaksanaan suatu kegiatan atau program dan kebijakan dalam mewujudkan sasaran, tujuan, misi dan visi organisasi yang tertuang dalam perumusan skema strategis (strategic planning) suatu organisasi.

Kinerja (performance) menurut Bangun (2012:231) adalah hasil pekerjaan yang dicapai seseorang berdasarkan persyaratan-persyaratan pekerjaan (job requirement).

Selanjutnya definisi kinerja menurut mangkunegara (2008:67) "kinerja adalah hasil kerja secara kualitas dan kuantitas yang dicapai seseorang pegawai dalam melaksanakan tugasnya sesuai dengan tanggung jawab yang diberikan kepadanya".

Sedangkan definisi kinerja menurut Tjutju Yunarsih dan Suwanto (2008:161) menyatakan bahwa "Kinerja merupakan prestasi yang nyata ditampilkan seseorang setelah yang bersangkutan menjalankan tugas dan perannya dalam organisasi”. 


\section{Paradigma Penelitian}

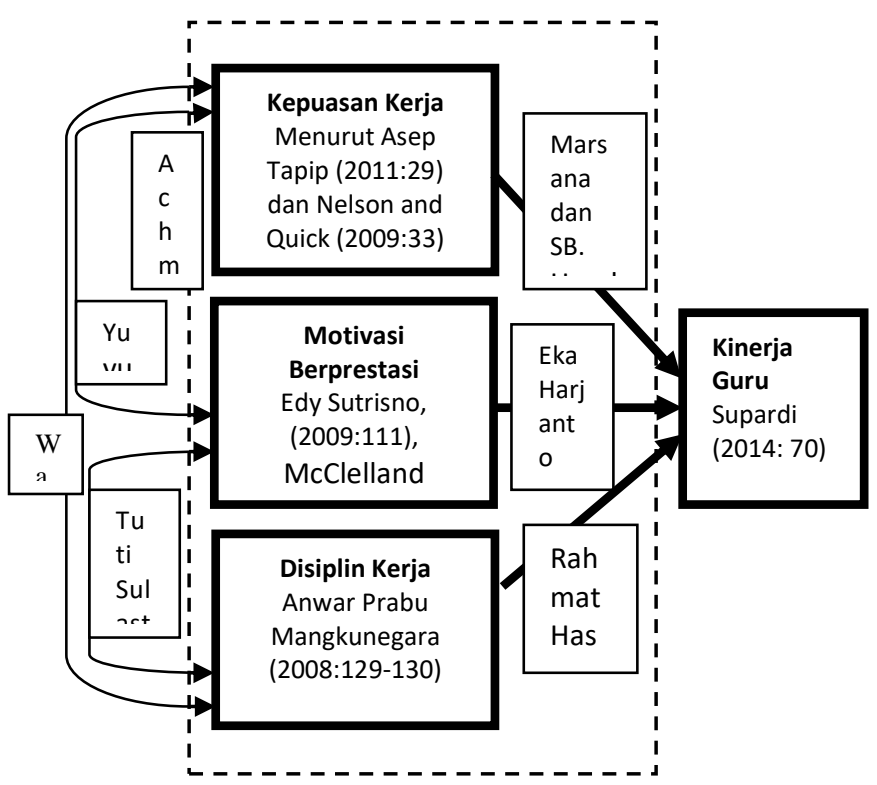

\section{Gambar 2.1. Paradigma Penelitian}

\section{Hipotesa Penelitian}

Hipotesis pada penelitian ini sebagai jawaban sementara dari rumusan masalah, sehingga berdasarkan kerangka pemikiran di atas hipotesis penelitian ini adalah sebagai berikut:

1. Diduga terdapat pengaruh Kepuasan Kerja Terhadap Kinerja Guru SMA dan SMK Se Kecamatan Pebayuran Kabupaten Bekasi.

2. Diduga terdapat pengaruh Motivasi Berprestasi Terhadap Kinerja Guru SMA dan SMK Se Kecamatan Pebayuran Kabupaten Bekasi.

3. Diduga terdapat pengaruh Disiplin Kerja Terhadap Kinerja Guru SMA dan SMK Se Kecamatan Pebayuran Kabupaten Bekasi.

4. Diduga terdapat pengaruh Simultan Kepuasan Kerja, Motivasi Berprestasi dan Disiplin Kerja Terhadap Kinerja Guru SMA dan SMK Se Kecamatan Pebayuran Kabupaten Bekasi.

\section{METODE PENELITIAN JENIS PENELITIAN}

Dalam penelitian ini menggunakan metode penelitian deskriptif dan verifikatif.

Menurut Sugiyono (2012:35), penelitian deskriptif adalah penelitian yang dilakukan untuk mengetahui nilai variabel mandiri, baik satu variabel atau lebih (independent) tanpa membuat perbandingan atau menghubungkan dengan variabel yang lain.

Penelitian verifikatif menurut Sugiyono (2012:3) bahwa metode penelitian kuantitatif yang digunakan untuk penelitian populasi atau sampel tertentu, dan analisis data bersifat statistik dengan tujuan untuk menguji hipotesis yang telah ditetapkan.

Tujuan dari penelitian deskriptif adalah untuk memperoleh gambaran secara sistematis mengenai kepuasan kerja, motivasi berprestasi, disiplin kerja sebagai variabel bebas dan 
kinerja guru sebagai variabel terikat, sedangkan secara verifikatif bertujuan untuk menguji hipotesis dengan perhitungan statistik.

\section{Operasionalisasi Variabel}

Variabel penelitian pada dasarnya adalah segala sesuatu yang berbentuk apa saja yang ditetapkan oleh peneliti untuk dipelajari sehingga diperoleh informasi tentang hal tersebut, kemudian ditarik kesimpulannya.

Dalam penelitian ini peneliti menggunakan tiga variabel yaitu dua variabel bebas $\left(\mathrm{X}_{1}\right.$, $\mathrm{X}_{2}$ dan $\mathrm{X}_{2}$ ) dan satu variabel terikat $(\mathrm{Y})$. Dalam hal ini variabel $\mathrm{X}_{1}$ adalah kepuasan kerja, variabel $\mathrm{X}_{2}$ adalah motivasi berprestasi dan variable $\mathrm{X}_{3}$ adalah disiplin kerja merupakan variabel yang mempengaruhi variabel $\mathrm{Y}$ yaitu kinerja guru.

\section{Sumber Dan Cara Penentuan Data/Informasi}

Jenis data yang digunakan peneliti dalam penelitian adalah data primer dan sekunder.

1. Data Primer

Menurut Sugiyono (2012:137) menjelaskan bahwa Sumber primer adalah sumber data yang langsung memberikan data kepada pengumpul data. Pengumpulan data primer dalam penelitian ini melalui cara menyebarkan kuesioner dan melakukan wawancara secara langsung dengan pihak-pihak yang berhubungan dengan penelitian yang dilakukan.

\section{Data Sekunder}

Menurut Sugiyono (2012:137) menjelaskan bahwa Sumber sekunder adalah sumber data yang diperoleh dengan cara membaca, mempelajari dan memahami melalui media lain yang bersumber dari literatur, buku-buku, serta dokumen perusahaan.

\section{Populasi Dan Sampel}

Populasi dalam penelitian ini terdiri dari populasi guru pada SMA dan SMK di Kecamatan Pebayuran, yang terdiri dari 151 orang.

Menurut Sugiyono (2013:149) Sampel adalah bagian jumlah dan karakteristik yang dimiliki oleh populasi tersebut. Pengambilan sampel yang dilakukan didalam penelitian ini adalah dengan menggunakan metode sampling jenuh. Semua anggota populasi dijadikan sampel untuk membuat generalisasi dengan kesalahan yang relative kecil. Dengan jumlah populasi pegawai sebanyak 151 orang. Maka sampel yang digunakan sama yaitu 151 orang. (Sugiono : $2013: 152$ ).

\section{Teknik Pengumpulan Data}

Pada penelitian ini menggunakan metode pengumpulan data sebagai berikut :

1. Penelitian lapangan (Field Research) dalam penelitian lapangan tersebut penulis menggunakan beberapa prosedur yaitu :
a. Angket
b. Observasi
c. Wawancara

Pada penelitian ini, penulis melakukan penyebaran angket kepada sampel yang ada di SMA dan SMK di Pebayuran.

2. Penelitian Kepustakaan (Library Research) yaitu mencari, mempelajari dan mengumpulkan teori serta bahan-bahan yang mendukung bagi penulis dengan 
mempelajari informasi dari beberapa literature yang berkaitan dengan masalah yang sedang diteliti penulis.

\section{Rancangan Analisis dan Uji Hipotesis Rancangan Analisis Deskriptif}

Analisis Statistik Deskriptif adalah statistic yang digunakan untuk menganalisa data dengan cara mendeskripsikan atau menggambarkan data yang telah terkumpul sebagaimana adanya tanpa bermaksud membuat kesimpulan yang berlaku untuk umum atau generalisasi. (Sugiyono, 2012:147)

Analisis deskriptif dalam penelitian ini menggunakan rentang skala untuk menganalisis data dengan cara menggambarkan kepuasan kerja, motivasi berprestasi, disiplin kerja dan kinerja pegawai guru.

Dalam penelitian ini untuk menganalisis data hasil survey yang berasal dari hasil pengukuran yaitu dengan menggunakan instrument dari skala likert.

\section{Uji Hipotesis \\ Uji Hipotesis (Uji t)}

Untuk mengetahui besarnya pengaruh masing-masing variabel independen secara individual (parsial) terhadap variabel dependen. Hasil uji $t_{\text {hitung }}$ ini ada pada output perangkat lunak,

dapat dilihat pada tabel coefficient level of significant yang digunakan sebesar $5 \%$ atau (a) = 0,05. Apabila $t_{\text {hitung }}>t_{\text {tabel }}$ maka Ho ditolak dan $\mathrm{H} 1$ diterima, artinya variabel independen

secara parsial tidak mempunyai pengaruh yang signifikan terhadap variabel dependen.

\section{HASIL DAN PEMBAHASAN}

\section{A. AnalisisDeskriptif}

\section{1) Analisis Validitas Data}

Pada kesempatan ini uji validitas dilakukan dengan melihat korelasi antara skor masing-masing item pernyataan dengan skor total, selanjutnya hasil korelasi pada masingmasing item di bandingkan dengan nilai kritis. Menurut Masrum yang dikutip oleh Sugiyono (2001), biasanya syarat minimum untuk dianggap valid adalah $r$ instrumen $=0,361$, sehingga jika korelasi (r) instrumen tersebut kurang dari 0,361 maka, dinyatakan tidak valid.

\section{2) Analisis Reliabilitas}

Nilai Standar reliabilitas didasarkan pada pendapat Nunnaly dalam Danang Atmodjo (2005) bahwa untuk penelitian ilmiah, standar nilai reliabilitas 0,60 atau 0,50 sudah cukup.

\section{Uji Normalitas}

Pengujian suatu data dalam penelitian sangat penting. Hal ini dimaksudkan untuk melihat sejauh mana kenormalan suatu data tersebar. Uji normalitas tersebut dilakukan dengan menggunakan uji liliefors yang dianalisis dengan menggunakan program Statistical Product and Service Solution (SPSS) 16.0 for windows. Cara untuk menentukan data berdistribusi normal atau tidak dengan melihat grafik distribusi normal serta dengan melakukan pengujian Kolmogorov Smirnov dengan kriteria sebagai berikut:

- Angka Signifikan (sig) > 0,05 maka data berdistribusi normal 
- Angka Signifikan (sig) < 0,05 maka data tidak berdistribusi normal.

B. Pengujian Hipotesis

a. Hipotesis Pengaruh Variabel Secara Parsial

1. Hipotesis Pengaruh Kepuasan Kerja (X1) terhadap Kinerja (Y)

Tabel 4.1

Hasil Koefisien Parsial Kepuasan

Guru terhadap Kinerja

Coefficients $^{\mathrm{a}}$

\begin{tabular}{|c|c|c|c|c|}
\hline \multicolumn{2}{|c|}{$\begin{array}{l}\text { Unstanda } \\
\text { rdized } \\
\text { Coefficie } \\
\text { nts } \\
\end{array}$} & $\begin{array}{c}\text { Stand } \\
\text { ardize } \\
\mathrm{d} \\
\text { Coeffi } \\
\text { cients }\end{array}$ & & \\
\hline B & $\begin{array}{c}\text { Std. } \\
\text { Erro } \\
\mathrm{r}\end{array}$ & Beta & $\mathrm{t}$ & Sig. \\
\hline $\begin{array}{r}11 . \\
784 \\
.79 \\
0\end{array}$ & $\begin{array}{r}1.95 \\
0 \\
.036\end{array}$ & .874 & $\begin{array}{r}6.04 \\
1 \\
21.9 \\
80\end{array}$ & $\begin{array}{r}.00 \\
0 \\
.00 \\
0 \\
\end{array}$ \\
\hline
\end{tabular}

Berdasarkan tabel di atas, dapat diketahui bahwa pengaruh parsial Kepuasan Guru ( $\left.\mathrm{X}_{1}\right)$ terhadap Kinerja Guru (Y) sebesar 0,874. Selanjutnya dengan memperhatikan tabel tersebut, didapat nilai sig 0,000 yang lebih kecil dari nilai probabilitas 0,05 atau $0,000<$ 0,05. Dengan demikian maka $\mathrm{H}_{0}$ ditolak dan $\mathrm{H}_{1}$ diterima. Sehingga dapat disimpulkan bahwa Kepuasan guru $\left(\mathrm{X}_{1}\right)$ berpengaruh secara signifikan terhadap Kinerja Guru (Y).

2. Hipotesis Pengaruh Motivasi Berprestasi (X2) terhadap Kinerja (Y)

Tabel 4.2

Hasil Koefisien Parsial

Motivasi Berprestasi Guru

terhadap Kinerja

Coefficients $^{\mathbf{a}}$

\begin{tabular}{|c|c|c|c|c|c|}
\hline & $\begin{array}{l}\text { Un } \\
\text { ar } \\
\text { Co }\end{array}$ & $\begin{array}{l}\text { and } \\
\text { zed } \\
\text { ficie } \\
\text { s }\end{array}$ & $\begin{array}{c}\text { Stan } \\
\text { dard } \\
\text { ized } \\
\text { Coef } \\
\text { ficie } \\
\text { nts }\end{array}$ & & \\
\hline Model & B & $\begin{array}{l}\text { Std. } \\
\text { Err } \\
\text { or }\end{array}$ & Beta & $\mathrm{T}$ & $\begin{array}{l}\mathrm{Si} \\
\text { g. }\end{array}$ \\
\hline
\end{tabular}

86. 


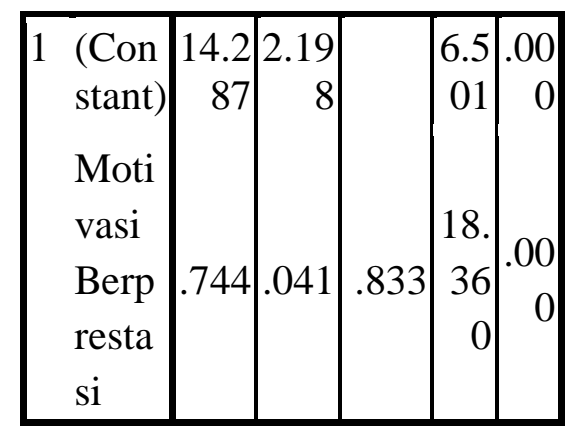

Berdasarkan tabel di atas, dapat diketahui bahwa pengaruh parsial Motivasi Berprestasi Guru $\left(\mathrm{X}_{2}\right)$ terhadap Kinerja Guru (Y) sebesar 0,833. Selanjutnya dengan memperhatikan tabel tersebut, didapat nilai sig 0,000 yang lebih kecil dari nilai probabilitas 0,05 atau $0,000<0,05$. Dengan demikian maka $\mathrm{H}_{0}$ ditolak dan $\mathrm{H}_{1}$ diterima. Sehingga dapat disimpulkan bahwa Motivasi Berprestasi Guru $\left(\mathrm{X}_{2}\right)$ berpengaruh secara signifikan terhadap Kinerja Guru (Y).

3. Hipotesis Pengaruh Kedisiplinan (X3) terhadap Kinerja (Y)

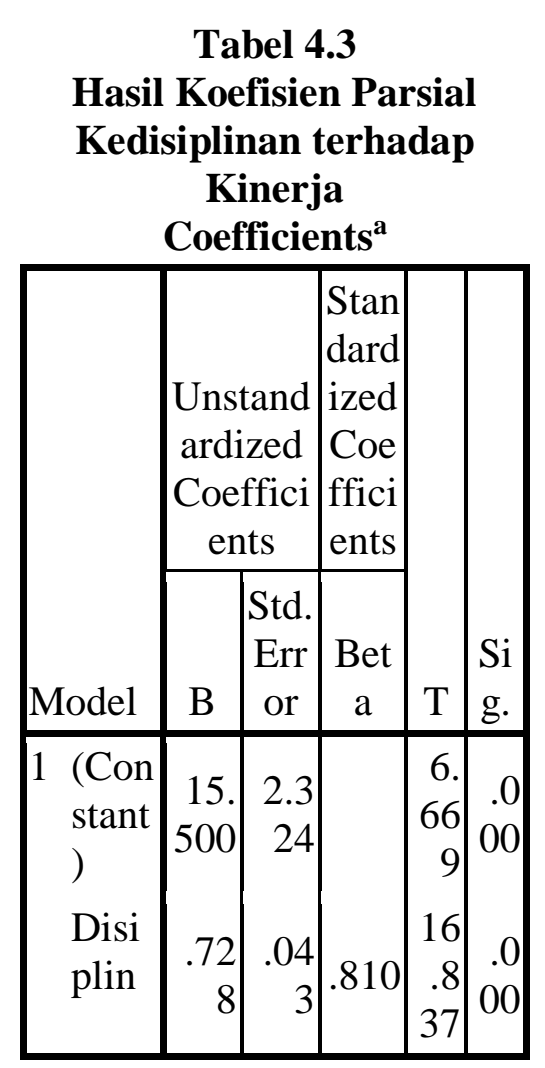

Berdasarkan tabel di atas, dapat diketahui bahwa pengaruh parsial Kedisiplinan $\left(\mathrm{X}_{3}\right)$ terhadap Kinerja Guru (Y) sebesar 0,810. Selanjutnya dengan memperhatikan tabel tersebut, didapat nilai sig 0,000 yang lebih kecil dari nilai probabilitas 0,05 atau 0,000<0,05. Dengan demikian maka $\mathrm{H}_{0}$ ditolak dan $\mathrm{H}_{1}$ diterima. Sehingga dapat disimpulkan bahwa Kedisiplinan $\left(\mathrm{X}_{3}\right)$ berpengaruh secara signifikan terhadap Kinerja Guru (Y). 
Tabel 4.4

\section{Hasil Koefisien korelasi (R) dan Koefisien Determinasi $\left(\mathbf{R}^{2}\right)$ Pengaruh Simultan Kepuasan Kerja, Motivasi Berprestasi dan Kedisiplinan Terhadap Kinerja Guru}

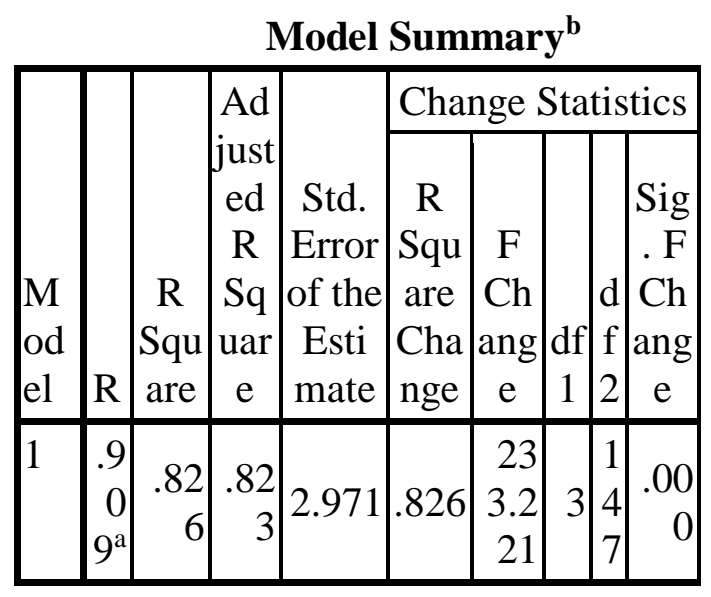

Berdasarkan tabel di atas, dapat diketahui bahwa terdapat pengaruh yang signifikan antara variabel bebas Kepuasan kerja, motivasi berprestasi dan kedisiplinan terhadap variabel terikat Kinerja Guru sebesar 0,909.

\section{Pembahasan Deskriptif}

Adapun pembahasan dari metode deskriptif mengenai masing-masing variabel dalam penelitian ini dapat diuraikan sebagai berikut.

1. Kontribusi yang diberikan variabel kepuasan guru terhadap kinerja guru sebesar 76,3 $\%$ menunjukkan bahwa guru yang memiliki kepuasan yang besar akan lebih mampu menciptakan suasana belajar yang baik juga, sehingga kinerja yang dilakukannya pun dapat terwujud secara optimal. Hal ini berarti bahwa ketika kinerja seorang guru kurang baik, maka peningkatan kepuasan kerjanya harus ditingkatkan semaksimal mungkin. Hal ini berarti bahwa kepuasan kerja seorang guru akan berimplikasi atau berkontribusi positif terhadap peningkatan kinerjanya.

2. Kontribusi yang diberikan variabel motivasi berprestasi guru terhadap kinerja guru sebesar 69,3\% menunjukkan bahwa guru yang memiliki motivasi berprestasi yang besar akan lebih mampu melaksanakan pembelajaran yang baik juga, sehingga kinerja yang dilakukannya pun dapat terlaksana secara optimal. Hal ini berarti bahwa ketika kinerja seorang guru kurang baik, maka mengembangkan motivasi berprestasinya harus dikembangkan semaksimal mungkin. Hal ini menunjukkan bahwa motivasi berprestasi seorang guru akan berimplikasi atau berkontribusi positif terhadap peningkatan kinerjanya.

3. Kontribusi yang diberikan variabel kedisiplinan guru terhadap kinerja guru sebesar 65,6 \% menunjukkan bahwa guru yang memiliki karakter disiplin yang tinggi akan lebih mampu menerapkan pembelajaran belajar yang baik juga, sehingga kinerja yang dilakukannya pun dapat terwujud secara optimal. Hal ini berarti bahwa ketika kinerja seorang 
guru kurang baik, maka peningkatan disiplin dalam bekerja harus ditingkatkan semaksimal mungkin. Hal ini berarti bahwa displin kerja seorang guru akan berimplikasi atau berkontribusi positif terhadap peningkatan kinerjanya.

4. kontribusi/determinasi simultan variabel Kepuasan kerja, motivasi berprestasi dan kedisiplinan terhadap variabel terikat Kinerja Guru adalah dengan mengkuadratkan nilai koefisien $R$ pada tabel di atas. Dengan demikian kontribusi yang diberikan adalah sebesar $0,909^{2} \times 100 \%=82,6 \%$. Hal ini menunjukkan bahwa secara simultan variabel Kepuasan kerja $\left(\mathrm{X}_{1}\right)$, motivasi berprestasi $\left(\mathrm{X}_{2}\right)$ dan kedisiplinan $\left(\mathrm{X}_{3}\right)$ memberikan kontribusi sebesar $82,6 \%$ terhadap Kinerja Guru (Y).

\section{Pembahasan Verifikatif}

1. pengujian hipotesis tentang pengaruh kepuasan kerja guru terhadap kinerjanya diperoleh koefisien parsialnya sebesar 0,874 . Hal ini menunjukkan kontribusi yang diberikan variabel kepuasan kerja guru terhadap kinerjanya sebesar $0,874^{2}$ x $100 \%=76,3 \%$. Cukup besarnya sumbangsih yang diberikan variabel kepuasan kerja guru secara parsial terhadap kinerjanya menunjukkan bahwa kinerja yang baik harus didasari oleh kepuasan kerja yang baik pula. Selanjutnya pengaruh parsial tersebut juga bernilai signifikan karena dilihat dari hasil uji t dengan t hitung $>\mathrm{t}$ probability sig $(21,980>0.000)$ untuk alfa $(\alpha)=0,01$

2. hasil pengujian hipotesis tentang pengaruh motivasi berprestasi guru secara parsial terhadap kinerjanya diperoleh koefisien korelasinya sebesar 0,833. Hal ini menunjukkan kontribusi yang diberikan variabel motivasi berprestasi guru secara parsial terhadap kinerjanya sebesar $0,833^{2}$ x $100 \%=69,3 \%$. Cukup besarnya sumbangsih yang diberikan variabel motivasi berprestasi guru secara parsial terhadap kinerjanya menunjukkan bahwa kinerja yang baik harus akan muncul dari motivasi berprestasi seorang guru. Selanjutnya pengaruh parsial tersebut juga bernilai signifikan karena dilihat dari hasil uji t dengan $t$ hitung $>\mathrm{t}$ probability sig $(18,360>0.000)$ untuk alfa $(\alpha)=0,01$

3. hasil pengujian hipotesis tentang pengaruh kedisiplinan guru secara parsial terhadap kinerjanya diperoleh koefisien korelasinya adalah 0,810 . Hal ini menunjukkan kontribusi yang diberikan variabel kedisiplinan guru secara parsial terhadap kinerjanya sebesar $0,810^{2} \mathrm{x}$ $100 \%=65,6 \%$. Selanjutnya pengaruh parsial tersebut juga bernilai signifikan karena dilihat dari hasil uji t dengan t hitung $>\mathrm{t}$ probability sig $(16,837>0.000)$ untuk alfa $(\alpha)=0,01$

4. hasil pengujian hipotesis tentang pengaruh simultan antara variabel bebas Kepuasan kerja, motivasi berprestasi dan kedisiplinan terhadap variabel terikat Kinerja Guru sebesar 0,909. Hal ini menunjukkan kontribusi yang diberikan variabel bebas secara simultan terhadap kinerjanya sebesar $0,909^{2} \times 100 \%=82,6 \%$. Selanjutnya pengaruh simultan tersebut juga bernilai signifikan karena dilihat dari hasil uji $\mathrm{F}$ dengan $\mathrm{F}$ hitung $>\mathrm{F}$ probability sig $(233,221>0.000)$ untuk alfa $(\alpha)=0,01$

\section{KESIMPULAN DAN SARAN}

\section{a. Simpulan}

Berdasarkan hasil analisis data dan pembahasan yang dilakukan pada Bab IV, maka dapat disimpulkan hal-hal sebagai berikut:

1. Kinerja guru di SMA dan SMK se-Kecamatan Pebayuran Kabupaten Bekasi cukup baik. Hal ini didasarkan bahwa dari jumlah responden sebanyak 151 orang, skor tertinggi yang 
juga merupakan skor maksimal adalah 70 , skor terendah 39 , nilai rata-rata 54,21 , median 54, modus 56, varians 49,821 dan standar deviasi 7,058

2. Kepuasan Kerja guru di SMA dan SMK se-Kecamatan Pebayuran Kabupaten Bekasi cukup baik. Hal ini didasarkan bahwa dari jumlah responden sebanyak 151 orang, skor tertinggi yang juga merupakan skor maksimal adalah 70, skor terendah 36, nilai rata-rata 53,72, median 53, modus 52, varians 61,032 dan standar deviasi 7,812

3. Motivasi Berprestasi guru di SMA dan SMK se-Kecamatan Pebayuran Kabupaten Bekasi cukup baik. Hal ini didasarkan bahwa dari jumlah responden sebanyak 151 orang, skor tertinggi yang juga merupakan skor maksimal adalah 70 , skor terendah 34 , nilai rata-rata 53,68, median 53, modus 52, varians 62,447 dan standar deviasi 7,092

4. Kedisiplinan guru guru di SMA dan SMK se-Kecamatan Pebayuran Kabupaten Bekasi cukup baik. Hal ini didasarkan bahwa dari jumlah responden sebanyak 151 orang, skor tertinggi yang juga merupakan skor maksimal adalah 70 , skor terendah 36 , nilai rata-rata 53,21, median 52, modus 51, varians 61,701 dan standar deviasi 7,855.

5. Pengaruh parsial Kepuasan Kerja, Motivasi Berprestasi dan kedisiplinan terhadap kinerja guru di SMA dan SMK se-Kecamatan Pebayuran Kabupaten Bekasi

a. Secara parsial kepuasan kerja berpengaruh positif dan signifikan terhadap kinerja guru di SMA dan SMK se-Kecamatan Pebayuran Kabupaten Bekasi. Dengan besaran pengaruh 0,874 dan kontribusi determinasi sebesar $0,874^{2} \times 100 \%=76,3 \%$.

b. Secara parsial motivasi berprestasi berpengaruh positif dan signifikan terhadap kinerja guru di SMA dan SMK se-Kecamatan Pebayuran Kabupaten Bekasi. Dengan besaran pengaruh 0,833 dan kontribusi determinasi sebesar $0,833^{2}$ x $100 \%=69,3 \%$.

c. Secara parsial kedisiplinan berpengaruh positif dan signifikan terhadap kinerja guru di SMA dan SMK se-Kecamatan Pebayuran Kabupaten Bekasi. Dengan besaran pengaruh 0,810 dan kontribusi determinasi sebesar $0,810^{2} \times 100 \%=65,6 \%$.

6. Secara simultan Kepuasan Kerja, Motivasi Berprestasi dan kedisiplinan berpengaruh positif dan signifikan terhadap kinerja guru di SMA dan SMK se-Kecamatan Pebayuran Kabupaten Bekasi. Dengan besaran pengaruh 0,909 dan kontribusi determinasi sebesar $0,909^{2} \times 100 \%=82,6 \%$. Sedangkan secara individual juga memiliki pengaruh positif dan signifikan antara variabel-variabel bebas dengan variabel terikatnya, dengan rincian sebagai berikut :

a. Pengaruh individual Kepuasan Kerja terhadap kinerja guru sebesar 0,491 dan kontribusi determinasi sebesar $24,1 \%$

b. Pengaruh individual motivasi berprestasi terhadap kinerja guru sebesar 0,246 dan kontribusi determinasi sebesar $6,05 \%$

c. Pengaruh individual kedisiplinan terhadap kinerja guru sebesar 0,237 dan kontribusi determinasi sebesar $5,61 \%$

\section{b. Saran}

Berdasarkan kesimpulan dari penelitian di atas, di bawah ini diajukan beberapa saran sebagai berikut :

1. Kinerja guru di SMA dan SMK se-Kecamatan Pebayuran Kabupaten Bekasi terbilang cukup baik dan diharapkan dapat terus dipertahankan sehingga kualitas pendidikan menengah khususnya SMA dan SMK dapat terus meningkat. Dalam penciptaan kinerja yang baik, guru harus melibatkan diri melalui proses interaksi secara positif dan harmonis dengan semua unsur yang ada di lingkungan organisasi

2. Agar kepuasan kerja guru dapat terwujud dengan baik yang akan berimplikasi terhadap peningkatan kinerjanya, maka disarankan kepada sekolah untuk selalu memberikan 
peluang berupa pemberian tambahan insentif, memfasilitasi guru untuk mempererat hubungan sesama rekan kerja, menciptakan lingkungan kerja yang relatif lebih nyaman bagi guru, mengembangkan keterampilan dan kemampuan pada gurunya. Dengan demikian, jika hal tersebut dapat direalisasikan maka kepuasan kerja guru akan terasa dan peningkatan kinerja guru akan muncul dan menguntungkan bagi sekolah

3. Peningkatan motivasi berprestasi guru di SMA dan SMK se-Kecamatan Pebayuran Kabupaten Bekasi yang sudah cukup baik dan diharapkan dapat terus dimaksimalkan dengan cara mengkondusifkan lingkungan sekolah yang kompetitif sehingga dapat memacu guru untuk meningkatkan motivasi berprestasi yang ada dalam dirinya

4. Hasil penelitian menunjukkan bahwa kedisiplinan guru di sekolah ini sudah baik yang diukur dengan beberapa indikator. Namun indikator pemberian penjelasan tentang prosedur kerja perlu mendapat perhatian yang lebih agar tidak terjadi sebuah pelanggaran. Menjadi perhatian yang lebih oleh sekolah, karena mengingat pelanggaran sering terjadi karena kurang fahamnnya seorang guru terkait dengan prosedur kerja yang harusnya ia laksanakan. Dengan pemberian pemahaman prosedur tersebut diharapkan akan meminimalisir pelanggaran yang pada akhirnya kinerja guru akan meningkat

5. Kinerja guru di SMA dan SMK se-Kecamatan Pebayuran Kabupaten Bekasi dipengaruhi secara parsial oleh Kepuasan Kerja, Motivasi Berprestasi dan kedisiplinan guru. Oleh karena itu, guna meningkatkan kinerja guru, maka pimpinan dalam hal ini Kepala Sekolah diharapkan dapat memberikan kepuasan terhadap hasil pekerjaan yang sudah dilakukan oleh seorang guru. Begitupun dengan guru yang sudah seharusnya memiliki motivasi berprestasi dan berlaku disiplin terhadap apa yang sudah menjadi tugas dan tangung jawabnya.

6. Secara simultan Kepuasan Kerja, Motivasi Berprestasi dan kedisiplinan berpengaruh positif dan signifikan terhadap kinerja guru di SMA dan SMK se-Kecamatan Pebayuran Kabupaten Bekasi. Dengan demikian kinerja tidak akan tercapai dengan maksimal jika unsur kepuasan kerja, motivasi berprestasi dan kedispilinan tidak dilakukan secara bersamaan. Sehingga meningkatkan kepuasan kerja, motivasi berprestasi dan juga kedisiplinan seyogyanya dapat dilakukan secara maksimal dalam organisasi sekolah yang sudah terbangun. 


\section{DAFTAR PUSTAKA}

Dessler, Gary. 2011. Manajemen Sumber Daya Manusia. Indeks, Jakarta

Mangkunegara, A.A Anwar Prabu. 2008. Manajemen Sumber Daya Manusia

Perusahaan. Bandung: Remaja Rosda karya.

Hawadi, Reni Akbar Dkk. 2003. Kreativitas. Grasindo, Jakarta.

Hasbullah, Rahmat and AnoesyirwanMoeins. 2017. The Influnce Of Professionalism, Achievement Motivation And Empowerment Against The Work Discipline And Its Implication On Teacher Performance: Empirical Study On High School Teachers In Karawang Regency. International Journal of Business and Commerce Vol. 5, No.06, ISSN: 2225-2436. University of Singaperbangsa Karawang (UNSIKA) and UPI-YAI Doctoral Management Science Program. Jakarta Indonesia (Diakses tangal 1 Mei 2017, 00:16)

Rivai,Veithzal. 2010. Manajemen Sumber Daya Manusia untuk Perusahaan. Jakarta: Rineka Cipta.

Robbins, Stephen P \& Mary Coulter, 2010. Manajemen Edisi 10. Penerbit Erlangga, Jakarta. 